\title{
Novel Degradation Diagnosis Algorithm for Solar Cell Modules by Taking into Account Electrical Characteristics and Ambient Factors
}

\author{
Donghyun TAE, Hudong LEE, Daeseok RHO*
}

\begin{abstract}
The Korean national policies have enforced to spread the RES (renewable energy sources) as one of the alternative solutions to solve the environmental pollution problems caused by global climate change. Under these circumstances, installations of solar cell systems are considered due to the global concern in eco-friendly and renewable solar energy sources. Nevertheless, electrical performance results and lifetime of solar cell modules installed outside of the buildings have been gradually reduced due to the varied outer ambient circumstances such as temperature, humidity, ultra-violet rays that may cause the reduction of solar cell modules efficiency. Therefore, to solve these issues, this study aims to present a diagnosis algorithm and also perform a diagnosis algorithm to reduce a condition of solar cell modules by taking into account ambient factors and the electrical performance which is energetically related to annual degradation of solar cell modules. Furthermore, this study focused on the implementation of the diagnosis system of solar cell modules with the proposed evaluation algorithm. In addition, the results show that the proposed evaluation and diagnosis system of solar cell modules are practical and useful tools for the improvement of operational efficiency in the solar cell system.
\end{abstract}

Keywords: ambient factors; degradation of solar cell modules; diagnosis algorithm; electrical performance

\section{INTRODUCTION}

These days, the Korean national policies have enforced to spread the RES(renewable energy sources) as one of the alternative solutions to solve the environmental pollution problems caused by global climate change[1-4]. Hence, the installation of the solar cell system with a distribution system is the best manner to solve ambient pollution problems and energy crises. In addition, Korean government has actively promoted RPSrenewable portfolio standard) to expand $20 \%$ of RES until 2030 [8]. Furthermore, electrical production and lifetime of solar cell modules installed outside of buildings has been gradually reduced due to the varied outer environmental circumstances such as temperature, humidity, ultra-violet and so on, which may cause the degradation of solar cell modules [9, 10]. When solar cell modules are being operated at the field, it is difficult to reduce or prevent their deterioration at the operation stage because it can occur naturally depending on electrical or environmental factors. Therefore, this paper focuses on a study to improve operation efficiency of solar cell systems through proper maintenance of system operators based on the proposed algorithm, which can exactly evaluate deterioration of solar cell modules. And also, this paper proposes an algorithm which accurately evaluates deterioration type of solar cell modules according to various electrical characteristics or environmental factors. Furthermore, this paper implements a diagnosis system of solar cell modules based on the proposed algorithm. From the simulation results based on the proposed algorithm and diagnosis system of solar cell modules, it is confirmed that they are practical and useful tools for the improvement of operational efficiency in solar cell systems.

\section{DEGRADATION CHARACTERISTICS OF SOLAR CELL MODULES}

Generally, the solar cells are extremely sensitiveto the temperature and solar radiation in which the capability of generating is greatly varied according to the ambient state, temperature and solar radiation at solar cell modules, which can be expressed as shown in Fig. 1 and Fig. 2.

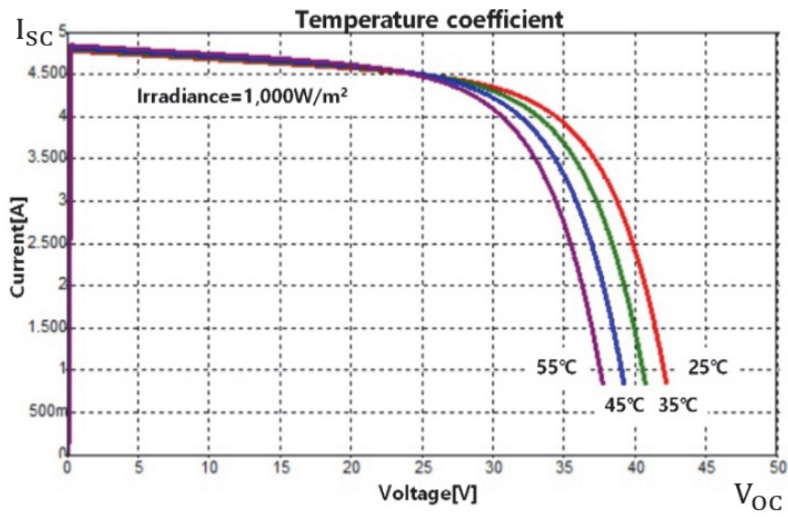

Figure 1 Characteristic curves of solar cell according to temperature

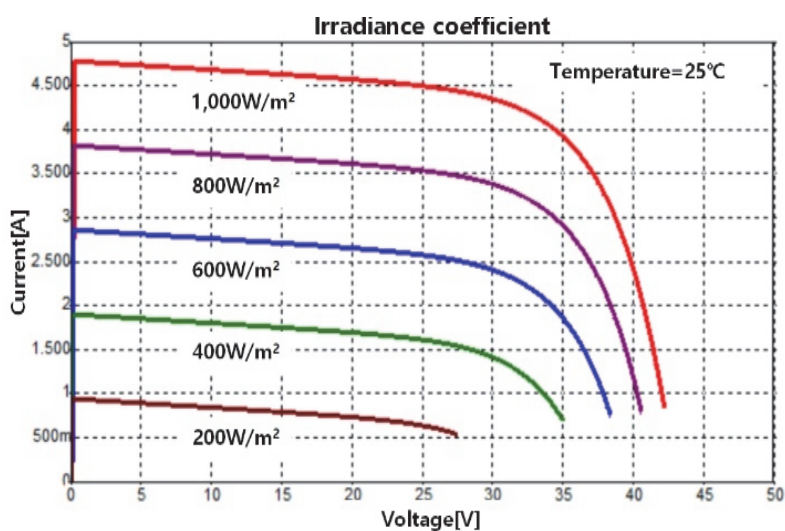

Figure 2 Characteristic curves of solar cell according to solar radiation

Here, open-circuit voltage $\left(V_{\mathrm{oc}}\right)$ and diode band gap of solar cell modules are reduced once the temperature rises, which is indicated as shown in Fig. 1. In addition, the power generation is reduced once the solar radiation gets lower which is impacted by the electrical factors such as $V_{\text {oc }}$, short-circuit current $\left(I_{\mathrm{sc}}\right)$, internal resistance. The $I_{\mathrm{sc}}$ represents the current flowing through the two output terminals in the solar cell modules in case of short-circuit. 
Furthermore, $V_{\text {oc }}$ shows a potential difference voltage between two output terminals in case of the open-circuit.

Therefore, electrical performance and period of the solar cell may be reduced by several degradation issues including ultra-violet, temperature and humidity, represented as shown in Fig. 3.

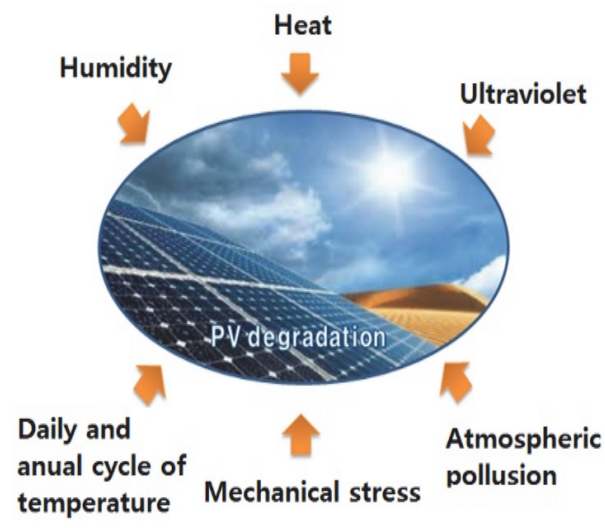

Figure 3 Deterioration factors of solar cell module

Also, from characteristics of aging degradation of 50 $\mathrm{kW}$ solar cell system introduced by the KEPRI (Korea electric power research institute) it is clear that $34 \%$ output power of solar cell has approximately decreased within 11 years after initial installation as shown in Fig. 4. In other words, $3.7 \%$ of power loss has annually occurred in the solar cell system.

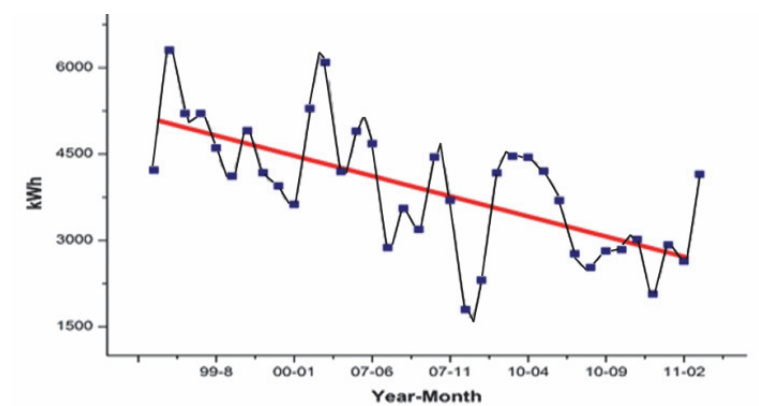

\begin{tabular}{|c|c|c|c|c|c|c|c|c|c|c|c|}
\hline Annual & $\mathbf{1}$ & $\mathbf{2}$ & $\mathbf{3}$ & $\mathbf{4}$ & $\mathbf{5}$ & $\mathbf{6}$ & $\mathbf{7}$ & $\mathbf{8}$ & $\mathbf{9}$ & $\mathbf{1 0}$ & $\mathbf{1 1}$ \\
\hline Remains & 96.3 & 92.7 & 89.3 & 86.0 & 82.8 & 79.7 & 76.8 & 73.9 & 71.2 & 68.5 & 66.0 \\
\hline Loss & 3.7 & 7.3 & 10.7 & 14.0 & 17.2 & 20.3 & 23.2 & 26.1 & 28.8 & 31.5 & 34.0 \\
\hline
\end{tabular}

Figure 4 Aging deterioration characteristics in solar cell system

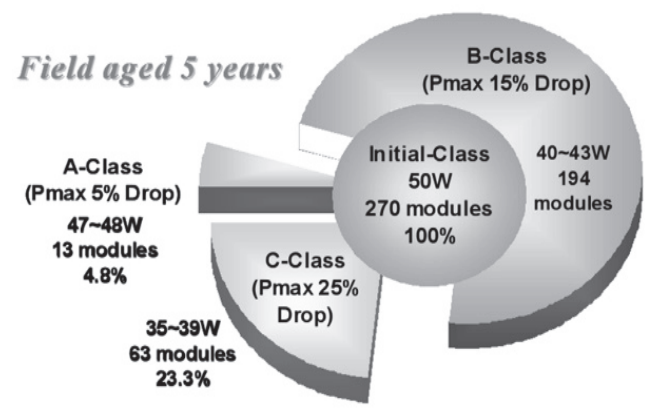

Figure 5 Electrical properties change on 5 years operated solar cell modules

Furthermore, as shown in Fig. 5, characteristics of electrical performance of solar cell modules were established by KIER (Korea institute of energy research) for 5 years. It demonstrates that electrical characteristics are decreased from $5 \%$ to $25 \%$ due to the ambient state.
Moreover, as shown in Tab. 1, a continuous study plan shows that annual evaluation characteristics of degradations of solar cell modules have been carried out by KIER. Based on the specified analysis of new degradation phenomena, yellowing phenomenon has shown more than 20 years operation of solar cell modules. And moisture movement and delamination phenomenon usually happened as swell. When solar cell modules are kept producing for over 10 years, it indicates a delamination, albinism, electrode corrosion and moisture movement phenomenon have occurred. Besides, there is no serious aging degradation happening within 5 years operations of solar cell modules, even though it is found that an output power rate is showing to be relatively high.

Table 1 Annual analysis on deterioration state of solar cell modules

\begin{tabular}{|c|c|c|c|c|}
\hline \multirow{2}{*}{ Aging phenomena } & \multicolumn{4}{|c|}{ Field Exposed / years } \\
\cline { 2 - 5 } & $<5$ & $\geq 5$ & $\geq 10$ & $\geq 20$ \\
\hline Hot spot & 9.9 & 0.4 & 0.0 & 0.0 \\
\hline Insulation breakdown & - & 1.1 & 0.3 & 0.1 \\
\hline $\begin{array}{c}\text { Output wire } \\
\text { corrosion }\end{array}$ & 10.1 & 3.4 & 6.9 & 2.1 \\
\hline Diode damage & - & 0.9 & 1.1 & 9.9 \\
\hline Interconnect/busbar & 40.1 & 30.1 & 0.6 & 0.2 \\
\hline Glass damage & - & 0.0 & 0.0 & 4.9 \\
\hline $\begin{array}{c}\text { Solar cell damage } \\
\text { and deformation }\end{array}$ & - & 2.1 & 0.4 & 0.6 \\
\hline $\begin{array}{c}\text { Encapsulant } \\
\text { discoloration and } \\
\text { deformation }\end{array}$ & - & 0.9 & 9.9 & 2.1 \\
\hline $\begin{array}{c}\text { Yellowing } \\
\text { phenomenon }\end{array}$ & - & 0.9 & 1.1 & 25.1 \\
\hline $\begin{array}{c}\text { Whitening } \\
\text { phenomenon }\end{array}$ & - & 9.9 & 29.9 & 9.9 \\
\hline Delamination & - & 25.1 & 20.1 & 19.9 \\
\hline Moisture permeation & - & 10.1 & 14.9 & 20.1 \\
\hline $\begin{array}{c}\text { Electrode corrosion } \\
\text { of solar cell }\end{array}$ & 30.9 & 15.1 & 15.0 & 5.1 \\
\hline Total & 100 & 100 & 100 & 100 \\
\hline $\begin{array}{c}\text { Generation decrease } \\
\text { rate / \% }\end{array}$ & $1.8-14.7$ & $13.1-13.6$ & $13.6-57.8$ & $20-34$ \\
\hline $\begin{array}{c}\text { Aging progress } \\
\text { intensity / \% }\end{array}$ & 10 & 30 & 80 & 100 \\
\hline $\begin{array}{c}\text { Evaluation site } \\
\text { number }\end{array}$ & 30 & 10 & 10 & 4 \\
\hline
\end{tabular}

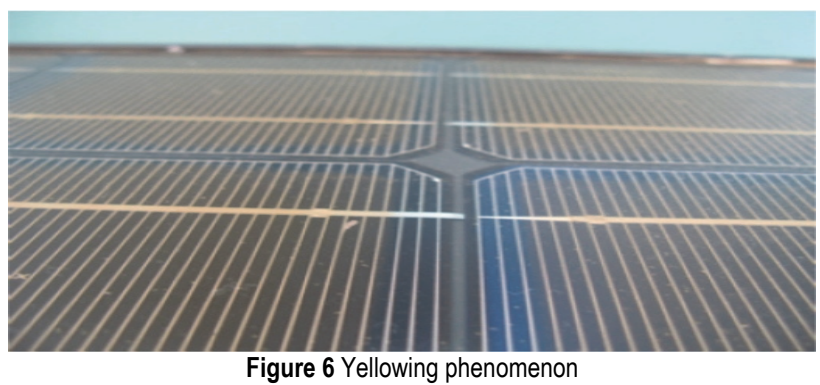

Where the yellowing phenomenon, as shown in Fig. 6, occurs because of exposure to ultraviolet or heat, EVA (ethylene vinyl acetate), which is a type of material used to avoid moisture permeation, turns yellow. In addition, in the event of extreme ageing degradation of PV modules, the capacity of output power is decreased annually from $5 \%$ to $15 \%$. In addition, albinism phenomenon has happened because of the air movement along with the EVA sheet and solar cell, tempered glasses, as shown in Fig. 7, Fig. 8 and it is corrupted with electrodes by the physical damage, as shown in Fig. 9. 

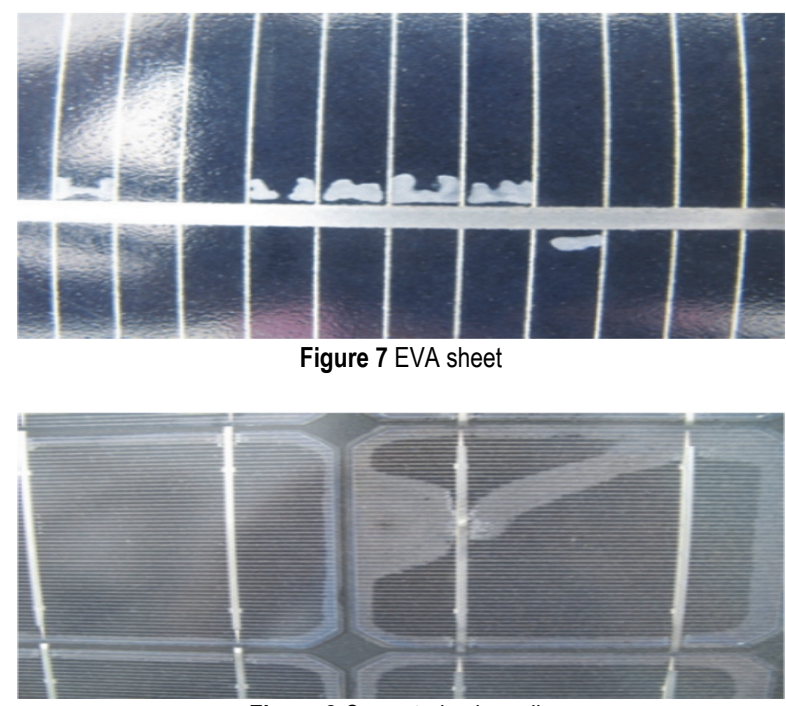

Figure 8 Corrupted solar cells

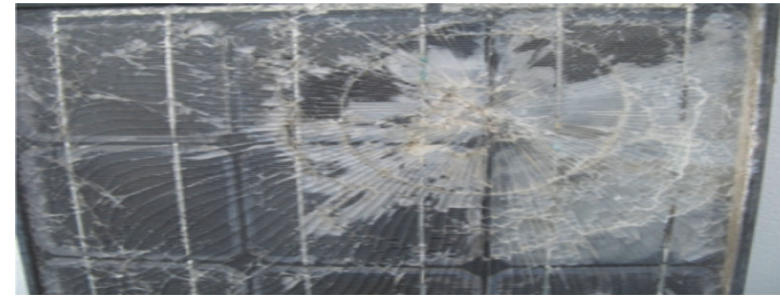

Figure 9 Physical damage

\section{DEGRADATION DIAGNOSIS ALGORITHM FOR SOLAR CELL MODULES}

\subsection{Degradation of Solar Cell Modules}

Degradation phenomenon consisting of an encapsulate ribbon wire corrosion, cell crack, back sheet delamination, discoloration, mayoccur at solar cell modules due to sustainable impact from other ambient factors. In particular, when solar cell modules are a long period of time exposed to heat, ultra-violet rays, encapsulate discoloration can decrease the transmittance rate of sun-ray and then reduce $I_{\mathrm{sc}}$ of solar cell modules. In addition, corrosion phenomenon of ribbon wire may happen by the moisture permeation into solar cell modules and then internal resistance is being raised. In addition, humidity with temperature variation causes delamination phenomenon of back sheets, decrease of $I_{\mathrm{sc}}$ and the crack phenomenon of solar cell modules may occur by the repetition progress of expansion and internal resistance is being increased. Thus, aging degradation phenomena of solar cell modules are classified by relevant ambient issues and electrical performance which is expressed in Tab. 2.

Table 2 Deterioration properties of solar cell module

\begin{tabular}{|c|c|c|}
\hline $\begin{array}{l}\text { Environmental } \\
\text { factor } \\
\end{array}$ & $\begin{array}{c}\text { Electrical } \\
\text { characteristics }\end{array}$ & Deterioration state \\
\hline $\begin{array}{l}\text { - high temperature } \\
\text { - ultraviolet }\end{array}$ & $\begin{array}{l}- \text { efficiency } \\
\text { decrease } \\
-I_{\text {sc }} \text { decrease }\end{array}$ & $\begin{array}{l}\text { - encapsulant } \\
\text { discoloration (yellowing, } \\
\text { whitening) }\end{array}$ \\
\hline $\begin{array}{l}\text { - humidity } \\
\text { - high temperature }\end{array}$ & $\begin{array}{l}\text { - FF (fill factor) } \\
\text { decrease } \\
\text { - } R_{\mathrm{s}} \text { increase }\end{array}$ & - ribbon wire corrosion \\
\hline $\begin{array}{l}\text { - humidity } \\
\text { - temperature } \\
\text { difference } \\
\end{array}$ & $\begin{array}{l}\text { efficiency } \\
\text { decrease } \\
-I_{\mathrm{sc}} \text { decrease } \\
\end{array}$ & - back sheet delamination \\
\hline $\begin{array}{l}\text { - temperature } \\
\text { difference }\end{array}$ & $\begin{array}{l}\text { - } R_{\mathrm{s}} \text { increase } \\
\text { - } F F \text { decrease }\end{array}$ & - cell crack \\
\hline
\end{tabular}

\subsection{Degradation Diagnosis Algorithm with Electrical Performance and Ambient Factors}

This research focused on the diagnosis algorithm for degradation state of solar cell modules to solve degradation issues in solar cell modules according to the reducing aging characteristics of solar cell modules which is distinguished by relevant ambient factors and electrical characteristics. Here, the detailed process for diagnosis algorithm by taking into account an electrical production and an ambient factor is as follows.

[Step 1] To compare the initial manufacture output power of solar cell modules with one of the used solar cell modules, it is measured at the time of maximum solar radiation during a day. The measured output power is modified with the value of STC(standard test condition) base because the initial value of solar cell modules is provided from the manufacturer that produced by the STC base in which the temperature and solar radiation of STC are $25^{\circ} \mathrm{C}$ and $1.000 \mathrm{~W} / \mathrm{m}^{2}$.

[Step 2] To convert output power of solar cell module into one of the STC temperature $\left(25^{\circ} \mathrm{C}\right)$, the compensated output power is expressed by the compensation coefficient of temperature $(\gamma)$ which is provided by the manufacturer and measured temperature $\left(T_{(t)}\right)$ at each time interval, as shown in Eq. (1).

$$
P_{(t)}^{*}=P_{(t)}+\gamma\left(T_{(t)}-25\right)
$$

where $P^{*}$ is compensated output power, $P$ is measured output power, $\gamma$ is compensation coefficient of temperature and $t$ is time interval.

[Step 3] By transforming output power measurement of solar cell modules into one of solar radiation of the STC $\left(1.000 \mathrm{~W} / \mathrm{m}^{2}\right)$, the quadratic linear regression equation is formulated as shown in Eq. (2), by using compensated output power calculated in Eq. (1).

$$
P_{(t)}^{*}=\alpha X_{(t)}^{2}+\beta X_{(t)}+e_{(t)}
$$

where $X$ is solar radiation at each time interval; $\alpha, \beta$, are compensation coefficient and $e$ is error.

To overcome a compensation coefficient for $\alpha, \beta$ in Eq. (2), the least square method to reduce the error is brought out as shown in Eq. (3).

$$
S=\sum\left(P_{(t)}^{*}-\alpha X_{(t)}^{2}+\beta X_{(t)}\right)^{2}=\sum e_{(t)}^{2}
$$

With derivatives for $\alpha, \beta$ in Eq. (3), the compensation coefficients $(\alpha, \beta)$ can be obtained as shown in Eq. (4) and Eq. (5), respectively.

$$
\begin{aligned}
& \alpha=\frac{\sum P_{(t)}^{*} \cdot X_{(t)}^{2} \cdot \sum X_{(t)}^{2}+\sum P_{(t)}^{*} \cdot X_{(t)} \cdot \sum X_{(t)}^{3}}{\left(\sum X_{(t)}^{3}\right)^{2}-\sum X_{(t)}^{4} \cdot \sum X_{(t)}^{2}} \\
& \beta=\frac{\sum X_{(t)}^{4} \cdot\left(\sum P_{(t)}^{*} \cdot X_{(t)}^{2} \cdot \sum X_{(t)}^{2}+\sum P_{(t)}^{*} \cdot X_{(t)} \cdot \sum X_{(t)}^{3}\right)}{\sum X_{(t)}^{3} \cdot\left(\sum X_{(t)}^{3}\right)^{2}-\sum X_{(t)}^{4} \cdot \sum X_{(t)}^{2}}- \\
& -\frac{\sum P_{(t)}^{*} \cdot X_{(t)}^{2}}{\sum X_{(t)}^{3}}
\end{aligned}
$$


Finally, modified output powers of solar cell module can be obtained with $\alpha, \beta, e$ and solar radiation(1.000 $\mathrm{W} / \mathrm{m}^{2}$ ) of STC, as shown in Eq. (6).

$P_{(N)}^{* *}=\alpha \cdot X_{\mathrm{STC}}^{2}+\beta \cdot X_{\mathrm{STC}}+e$

where, $P_{(N)}^{* *}$ is modified output power at STC and is solar radiation of $\mathrm{STC}$.

[Step 5] To compare the fixed output $\operatorname{power}\left(P_{(N)}^{* *}\right)$ of the solar cell module with an initial performance value for the diagnosis degradation condition of solar cell modules, If $P_{(N)}^{* *}$ is greater than output power of initial state $\left(P_{\text {initial }}\right)$,it can be evaluated as the normal one, if not, solar cell module is considered as abnormal one.

[Step 6] To evaluate and categorize a degradation condition of solar cell modules, calculate a $F F$ and $I_{\mathrm{sc}}$ which are expressed below in Eq. (7) and Eq. (8).

$$
\begin{aligned}
& F F=\frac{V_{\mathrm{m}} \cdot I_{\mathrm{m}}}{V_{\mathrm{oc}} \cdot I_{\mathrm{sc}}} \\
& I_{\mathrm{sc}}=I_{\mathrm{s}} \cdot N_{\mathrm{p}}\left[\exp \left(\frac{q \cdot V_{\mathrm{oc}}}{n \cdot k \cdot T \cdot N_{\mathrm{s}}}\right)-1\right] \times 100
\end{aligned}
$$

where, $V_{\mathrm{m}}$ is maximum voltage of solar cell module, $V_{\mathrm{oc}}$ is open-circuit voltage, $I_{\mathrm{m}}$ is maximum current of solar cell module, $I_{\mathrm{sc}}$ is short-circuit current, $I_{\mathrm{sc}}^{*}$ is short-circuit current of STC, $I_{\mathrm{s}}$ is equivalent reverse saturation current, $N_{\mathrm{p}}$ is the number of parallel connected solar cell modules, $N_{\mathrm{s}}$ is the number of series connected solar cell modules, $k$ is Boltzmann constant, $q$ is Coulomb constant, $T$ is temperature of solar cell module.

[Step 7] To confirm $F F$ and $I_{\text {sc }}$ of solar cell module with initial performance values provided by the manufacturer. If $F F$ of solar cell module is smaller than $F F$ of initial performance value, degradation condition of solar cell module can be categorized as ribbon wire corrosion or cell crack. On the other hand, if $I_{\mathrm{sc}}$ is smaller than $I_{\mathrm{sc}}$ of initial value, degradation condition of solar cell module can be classified as encapsulate discoloration or back sheet delamination.

[Step 8] To enhance a proper degradation diagnosis by the $F F$ in [Step 7], the ambient factors, for example, solar radiation, temperature and humidity is taken into account with the detailed categorization which is demonstrated in Tab. 1.

Hence, procedure algorithm of degradation diagnosis of solar cell modules is presented in Fig. 10.

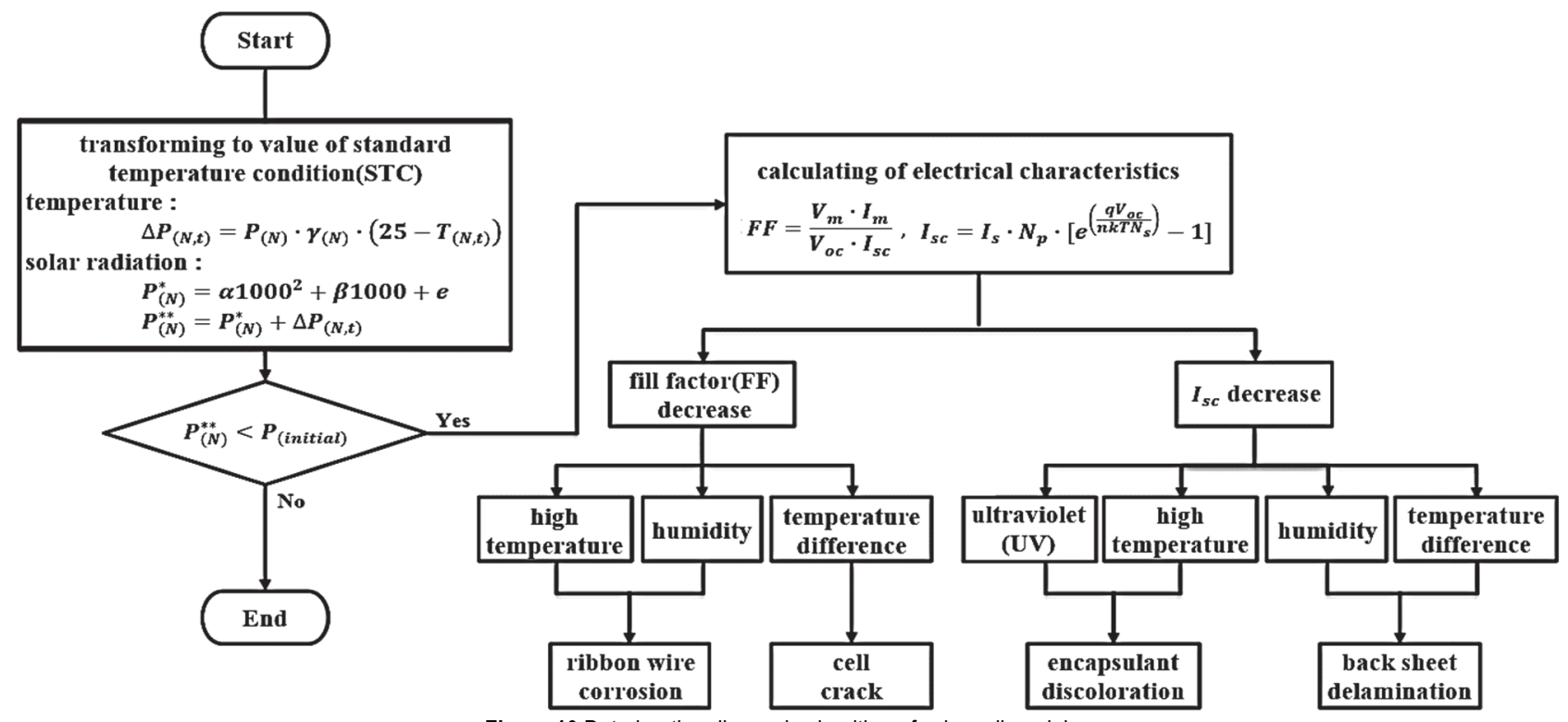

Figure 10 Deterioration diagnosis algorithm of solar cell modules

\section{IMPLEMENTATION OF DEGRADATION DIAGNOSIS SYSTEM FOR SOLAR CELL MODULES}

\subsection{Hardware System}

Based on the proposed algorithm, this section implements a hardware diagnostic system of the solar cell modules.

\subsubsection{Section of Solar Cell Modules}

\section{(a) Solar cell module section}

The solar cell module is categorized as single crystal cell and polycrystalline cell as mentioned in Fig. 11 and Fig. 12. An advantage of single crystal cell is that it is better in power generation capability than polycrystalline cell.
However the disadvantages present expensive price. And also, polycrystalline is a cheap price either in power generation efficiency. These days, the most usually used solar cell system is polycrystalline cell that is around $66.8 \%$ compared to single crystal cell. However, its power generation is approximately $12 \%$ and $17 \%$ depending on solar radiation. Because of that, there is better merit in using polycrystalline cell from the economic aspect.

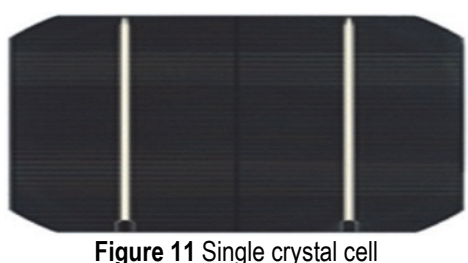




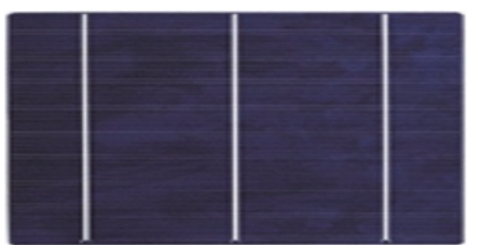

Figure 12 Polycrystalline cell

Thus, it is clear to utilize a polycrystalline cell to design the degradation diagnosis system for contributing to reduce the costs. Besides, every solar cell module is composed of 60 pieces of polycrystalline cell as indicated in Fig. 13, and output power of the maximum total is 250 W.

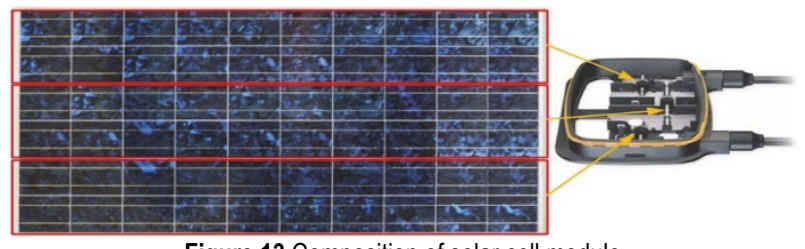

Figure 13 Composition of solar cell module

\section{(b) Evaluation of solar cell modules}

In general, the solar cell module is designed and implemented with series and parallel connection, when solar cell is connected by transfer wiring method in 3-phase inverters. Here, the voltage of solar cell power source is taken into consideration as initial voltage at each inverter(single phase inverter is $200 \mathrm{~V}, 3$-phase inverter is $300 \mathrm{~V}$ ) and is adjustable depending on varied connection types of solar cell modules in which 16 pieces of $250 \mathrm{~W}$ solar cell modules consist of a $4 \mathrm{~kW}$ solar cell, and the electrical characteristics of solar cell module are implemented as shown in Tab. 3. The wiring method of solar cell modules to interconnect with an inverter is presented as shown in Fig. 14. Here, S1 is switched on and $\mathrm{S} 2$ is switched off to compose the form that 8 series of solar cell modules are in parallel connection (operation voltage of solar cell power source is $280 \mathrm{~V}$ ) when it is connected to a single phase inverter. Contrary, $\mathrm{S} 1$ is switched off and $\mathrm{S} 2$ is switched on to compose 16 series connected solar cell modules in case of connecting 3-phase inverter.

Table 3 Electrical properties of solar cell module

\begin{tabular}{|l|c|}
\hline \multicolumn{1}{|c|}{ Classification } & Characteristics \\
\hline Temperature coefficient of power $/ \% /{ }^{\circ} \mathrm{C}$ & -0.428 \\
\hline Module efficiency $/ \%$ & 15.04 \\
\hline Short-circuit current $I_{\mathrm{sc}} / \mathrm{A}$ & 8.68 \\
\hline Open-circuit voltage $V_{\mathrm{oc}} / \mathrm{V}$ & 37.6 \\
\hline Current at $P_{\max }\left(I_{\mathrm{mp}}\right) / \mathrm{A}$ & 8.15 \\
\hline Voltage at $P_{\max }\left(V_{\mathrm{mp}}\right) / \mathrm{V}$ & 30.7 \\
\hline Rated power $P_{\max } / \mathrm{W}$ & 250 \\
\hline
\end{tabular}

\subsubsection{Data Measurement/Communication Section}

In addition, according to the data communication section implemented for changed collection using a data logger, the temperature, voltage in the range of $20 \mathrm{mV}-50$ $\mathrm{V}$ and humidity of up to $100 \% \mathrm{RH}$ are measured. Besides, TCP/IP communication protocol is applied to monitor data loggers. This device plays a role of transmitting data to a remote area by transforming measured data into $\mathrm{C}++$ language of the monitoring program in order to make monitoring and control available. Here the detailed function of a data logger is to upgrade the latest status information of each solar cell module which is collected through the gateway and manage it as swell. In addition, it can transfer the data through different types of network communications including an Ethernet, 4G, and Wi-Fi.

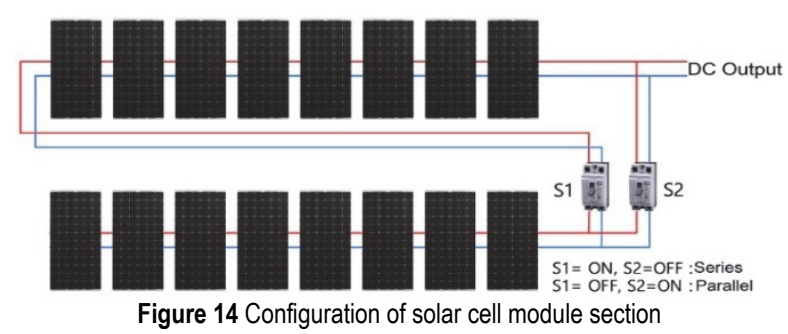

\subsubsection{Entire System}

As described earlier, this research has implemented a degradation diagnosis system of solar cell modules consisting of 4 sections including solar cell modules, data measurement devices, communication devices, and degradation diagnosis devices as shown in Fig. 15. Specifically, the section of solar cell modules is implemented by 16 modules of $250 \mathrm{~W}$ with 8 series and 2 parallel connections. In addition, the section of data measurement devices consists of various sensors to measure performance data (V \& I) voltage and current of each solar cell module and environmental data (solar radiation, temperature and humidity). And also, the section of the data communication device is designed to gather varied data from the section of data measurement devices, and to transmit the data into remote $\mathrm{DB}$ server. Furthermore, the section of degradation diagnosis devices consists of DB server and monitoring system, which is designed to store the data transmitted from the section of data communication device at DB server and to diagnose states of solar cell modules.

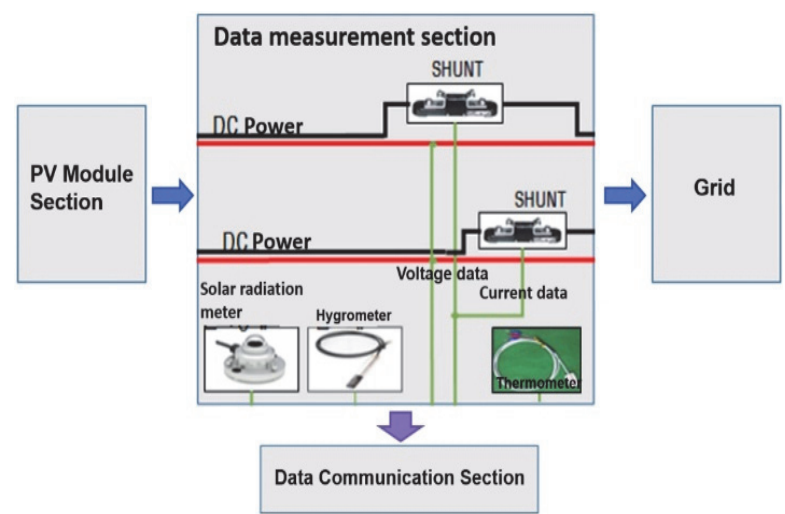

Figure 15 Block diagram of data measurement section

\subsection{Implementation of Software System}

Based on the proposed algorithm, this section implements the DBMS and software operation program for degradation diagnostic system of solar cell modules.

\subsubsection{Implementation of DBMS}

This paper implements an excitation system simulator based on the proposed optimal control algorithm. The main results of this paper are summarized as follows. To attain 
management of the data saved in the database server, this paper implements the DBMS(database management system) for the degradation diagnosis system by using MSSQL Server 2012 software. The transmitted data in DB server by the data logger are classified into maintenance data presented as shown in Tab. 4. Here, the management data such as surrounding climate, data of inverter data and solar cell module information and maintenance data include modified output power, performance characteristics of initial solar cell module and Degradation diagnosis information.

And also, for degradation diagnosis of solar cell system, data measurement in solar cell module and data ambient is arranged as shown in Tab. 5. In particular, essential importance data are categorized in voltage, current, temperature and number of modules of solar cell system and number of string. Therefore, it is simple for operator to easily recognize the location and condition at solar cell modules.

Table 4 Table item of DBMS

\begin{tabular}{|c|c|c|}
\hline Classifications & Table items & Contents \\
\hline \multirow{4}{*}{ operation data } & environment & data of surrounding climate \\
\cline { 2 - 3 } & inverter & state data of inverter \\
\cline { 2 - 3 } & solar cell module & state data of solar cell module \\
\hline \multirow{4}{*}{ maintenance data } & $\begin{array}{c}\text { modified output } \\
\text { power }\end{array}$ & $\begin{array}{c}\text { modified output power of solar } \\
\text { cell modules }\end{array}$ \\
\cline { 2 - 3 } & $\begin{array}{c}\text { initial solar cell } \\
\text { module }\end{array}$ & $\begin{array}{c}\text { performance data of initial } \\
\text { solar cell module }\end{array}$ \\
\cline { 2 - 3 } & deterioration & $\begin{array}{c}\text { information for deterioration } \\
\text { state of solar cell module }\end{array}$ \\
\hline
\end{tabular}

Table 5 Solar cell module basis measurement and environmental data

\begin{tabular}{|c|c|c|c|c|c|}
\hline \multicolumn{2}{|c|}{ Entries } & Requirement & $250 \mathrm{~kW}$ basis Requirement & $1 \mathrm{MW}$ basis Requirement & Note \\
\hline \multicolumn{2}{|c|}{ Site Number } & 2 & 2 & 2 & \\
\hline \multicolumn{2}{|c|}{ Date Time } & 8 & 8 & 8 & \\
\hline \multirow{6}{*}{$\begin{array}{c}\text { Environmental } \\
\text { Data Collection Devices }\end{array}$} & Wind Speed & 1 & \multirow{6}{*}{11} & \multirow{6}{*}{11} & \multirow{6}{*}{$\begin{array}{c}\text { One set of } \\
\text { environmental } \\
\text { data collection } \\
\text { devices } \\
\text { per site }\end{array}$} \\
\hline & $\begin{array}{l}\text { Horizontal Solar } \\
\text { Radiation }\end{array}$ & 2 & & & \\
\hline & Wind Direction & 2 & & & \\
\hline & Ambient Temperature & 2 & & & \\
\hline & Vertical Solar Radiation & 2 & & & \\
\hline & Humidity & 2 & & & \\
\hline
\end{tabular}

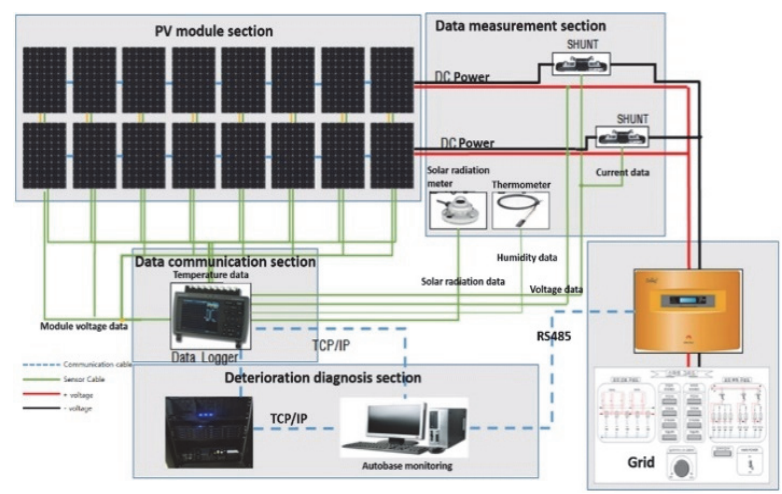

Figure 16 Configuration of deterioration diagnosis system

Besides, the entire capacity of data transferred to database server is approximately around 48.225 Byte by taking into account the use of 400 pieces of $250 \mathrm{~W}$ solar cell modules while 4 units of $250 \mathrm{~W}$ solar inverters and ambient data gathering devices consist of thermometer, radiation meter. Furthermore, it is essential to set the relationship among DB tables to search and analyze various data stored in the database server due to several requirements. For this reason, number of sites of the customer information table is set as the primer key to exclude an input of duplicate value and null value for efficiency among database tables. In addition, the site number is set as an external key in the module table, inverter table and ambient information table which is related to customer information to check and store the desired data in an easy way, which is illustrated as shown in Fig. 16.

\subsubsection{Implementation of Degradation Diagnosis Program}

With the degradation diagnosis algorithm for solar cell module described above, the degradation diagnosis schedule is implemented with a script statement of auto base $\mathrm{S} / \mathrm{W}$. Here, the main menu of degradation algorithm schedule of $4 \mathrm{~kW}$ of a solar cell is shown in Fig. 17 which displays the operation function of solar cell modules, information on inverter, information on ambient in a convenient way. Also, it is designed to simply find out operation condition and fault history by building submenus such as information on solar cell module, diagnosis position, power generation trend, report and database. And the design with function of each menu is demonstrated as shown in Tab. 6.

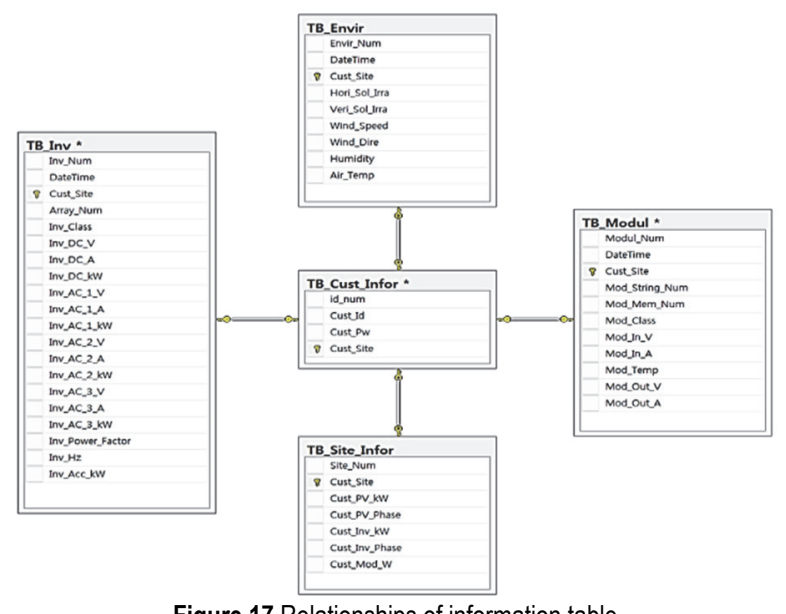

Figure 17 Relationships of information table

Table 6 Function and composition of each option in DB

\begin{tabular}{|c|l|}
\hline Menu & \multicolumn{1}{|c|}{ Function Definition } \\
\hline Main & $\begin{array}{l}\text { Weather condition check, } \\
\text { Real-time system development }\end{array}$ \\
\hline $\begin{array}{c}\text { Module } \\
\text { Information }\end{array}$ & $\begin{array}{l}\text { Check the current operating status (temperature and } \\
\text { power, current, voltage) of individual solar cell } \\
\text { modules }\end{array}$ \\
\hline Status Alert & Location and monitoring of individual modules \\
\hline Trend & Check to weather data trend, system power generation, \\
\hline Report & Report on the status of power generation by period \\
\hline DB & Search data collected from DB \\
\hline
\end{tabular}




\section{SIMULATION AND TEST RESULTS}

\subsection{Electrical Performance for Degradation Conditions}

In this section in order to find the $F F$ of initial condition of solar cell modules changed according to the degradation conditions, the $F F$, short $I_{\text {sc }}$ and $V_{\text {oc }}$ of the solar cell module. Here, the ribbon wire corrosion or yellowing characteristics happened and are compared to the initial characteristics of the solar cell modules, which is presented as shown in Tab. 7. And also, it is clear that to convert the electrical characteristics of ribbon wire corrosion of solar cell modules have slightly changed of 0.4 in $I_{\text {sc }}$, but has a greatly reduced by $7.3 \%$ in $V_{\text {oc }}$ and $4.6 \%$ in $F F$.

Table 7 Electrical properties of solar cell module with ribbon wire corrosion

\begin{tabular}{|l|c|c|c|}
\hline Parameter & Initial value & $\begin{array}{c}\text { Deterioration } \\
\text { value }\end{array}$ & $\begin{array}{c}\text { Deterioration rate } / \\
\%\end{array}$ \\
\hline$P_{\max } / \mathrm{W}$ & 81.23 & 70.22 & -13.6 \\
\hline$F F / \%$ & 74.4 & 69.77 & -4.6 \\
\hline$I_{\mathrm{sc}} / \mathrm{A}$ & 4.69 & 4.67 & -0.5 \\
\hline$V_{\mathrm{oc}} / \mathrm{V}$ & 23.4 & 21.7 & -7.3 \\
\hline
\end{tabular}

Furthermore, it is found that the solar cell module with yellowing characteristics influenced by UV ray and humidity is slightly reduced in electrical characteristics which is compared to initial characteristics as $1.2 \%$ of $V_{\mathrm{oc}}$ and $0.3 \%$ of $F F$, despite it is greatly reduced in $I_{\mathrm{sc}}$ by $12.4 \%$ as demonstrated in Tab. 8, so it is clear that the proposed algorithm of degradation diagnosis in this study can perform a proper diagnosis of degradation condition due to electrical performance of solar cell system which can be changed depending on the degradation conditions.

Table 8 Electrical properties of solar cell module with encapsulant discoloration

\begin{tabular}{|l|c|c|c|}
\hline Parameter & Initial value & $\begin{array}{c}\text { Deterioration } \\
\text { value }\end{array}$ & $\begin{array}{c}\text { Deterioration rate / } \\
\%\end{array}$ \\
\hline$P_{\max } / \mathrm{W}$ & 43.1 & 37.18 & -13.4 \\
\hline$F F / \%$ & 72.2 & 71.9 & -0.3 \\
\hline$I_{\mathrm{sc}} / \mathrm{A}$ & 3.32 & 2.91 & -12.4 \\
\hline$V_{\mathrm{oc}} / \mathrm{V}$ & 18.0 & 17.77 & -1.2 \\
\hline
\end{tabular}

\subsection{Degradation Characteristics for Environment Factors}

This paper analyzes a method of ambient factors including radiation, temperature and humidity in order to evaluate degradation condition which is categorized by electrical characteristics. Here, an analysis of degradation state according to the ambient factors used the accelerated degradation experimental data of solar cell modules performed according to IEC 61215 test standard. For example, temperature cycle test causes cracks at solar cell junction with different temperature and then the electrical characteristics of solar cell modules are illustrated in Tab. 9 which shows reduction of $0.8 \%$ in $V_{\text {oc }}$ and $3.0 \%$ in $F F$.

Table 9 Characteristics of accelerated temperature cycle test

\begin{tabular}{|l|c|c|c|}
\hline \multicolumn{1}{|c|}{ Parameter } & Initial value & $\begin{array}{c}\text { Deterioration } \\
\text { value }\end{array}$ & $\begin{array}{c}\text { Deterioration rate } / \\
\%\end{array}$ \\
\hline$P_{\max } / \mathrm{W}$ & 202 & 195.4 & -3.3 \\
\hline$F F / \%$ & 74.2 & 71.8 & -3.0 \\
\hline$I_{\mathrm{sc}} / \mathrm{A}$ & 7.89 & 7.93 & +0.6 \\
\hline$V_{\mathrm{oc}} / \mathrm{V}$ & 34.63 & 34.34 & -0.8 \\
\hline
\end{tabular}

Furthermore, as shown in Tab. 10, the humidity and high temperature test may cause the ribbon wire and EVA corrosion and then the electrical performance for solar cell shows a decrease of $1.7 \%$ in $I_{\text {sc }}$ and $0.7 \%$ in $F F$. Therefore, it is found that degradation condition of solar cell modules can be correctly evaluated by taking into account the ambient condition through the reality that the various electrical characteristics and each deterioration phenomenon occurred differently according to ambient factors.

Table 10 Characteristics of accelerated high temperature and humidity test

\begin{tabular}{|l|c|c|c|}
\hline \multicolumn{1}{|c|}{ Parameter } & Initial value & $\begin{array}{c}\text { Deterioration } \\
\text { value }\end{array}$ & $\begin{array}{c}\text { Deterioration rate } / \\
\%\end{array}$ \\
\hline$P_{\max } / \mathrm{W}$ & 201.9 & 198 & -2.5 \\
\hline$F F / \%$ & 74.5 & 73.8 & -0.7 \\
\hline$I_{\mathrm{sc}} / \mathrm{A}$ & 7.82 & 7.69 & -1.7 \\
\hline$V_{\mathrm{oc}} / \mathrm{V}$ & 34.72 & 34.69 & -0.2 \\
\hline
\end{tabular}

\subsection{Performance Evaluation of Degradation Diagnosis System}

This paper performs a test for gradation diagnosis of solar cell modules by considering encapsulate discoloration or ribbon wire corrosion phenomenon. In particular, module 1 (module [1-1]) of first sting in Fig. 18 reduces transferred rate of solar radiation by attaching a yellow cellophane sheet on surface of the module, and (module [2-2]) of second string is completely covering one cell to assume short-circuit for ribbon wire corrosion. The results of data measurement by the degradation diagnosis system are as shown in Tab. 11. It is confirmed that maximum current and $I_{\mathrm{sc}}$ in module [1-1] is decreased because of reduction in the solar radiation transmittance rate compared tothe initial characteristics of solar cell module, but the $F F$ has slightly changed. On the other hand, it is clear that $F F$ is greatly decreased from $77.1 \%$ to $68.4 \%$ in the module [2-2], in which the $I_{\mathrm{sc}}$ is almost the same.

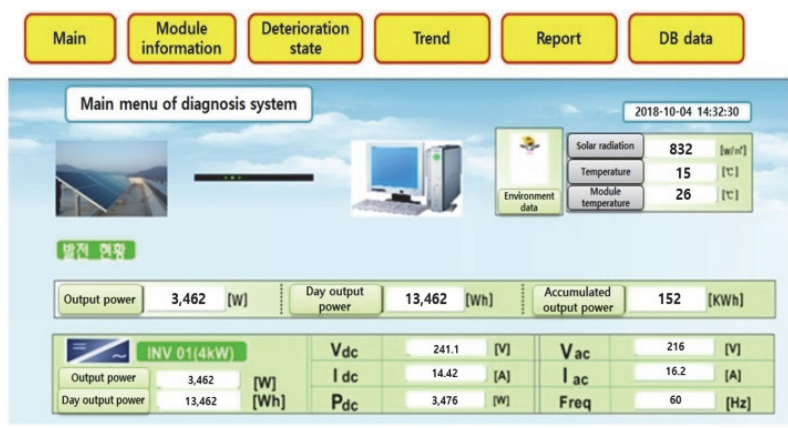

Figure 18 Main menu of deterioration diagnosis program

Table 11 Performance characteristics of solar cell modules

\begin{tabular}{|l|c|c|c|}
\hline \multicolumn{1}{|c|}{ Parameter } & Initial value & Module [1-1] & Module [2-2] \\
\hline$P_{\max } / \mathrm{W}$ & 250 & 223.49 & 164.5 \\
\hline$F F / \%$ & 77.1 & 77.2 & 68.4 \\
\hline$I_{\mathrm{sc}} / \mathrm{A}$ & 8.68 & 8.16 & 8.63 \\
\hline$V_{\mathrm{oc}} / \mathrm{V}$ & 37.6 & 35.7 & 27.8 \\
\hline$I_{\mathrm{m}} / \mathrm{A}$ & 8.15 & 7.5 & 8.2 \\
\hline$V_{\mathrm{m}} / \mathrm{V}$ & 30.7 & 30.3 & 20.4 \\
\hline
\end{tabular}

Besides, it is known where the proposed degradation diagnosis system as shown in Fig. 19 can be expressed by using the gauge bar function and performs theinstruction of an alert lamp according to encapsulant discoloration and back sheet phenomena as shown in Tab. 7 and Tab. 8 . Hence, it is known that degradation diagnosis system which is performed by the proposed degradation diagnosis 
algorithm evaluates degradation characteristics of the solar cell modules.

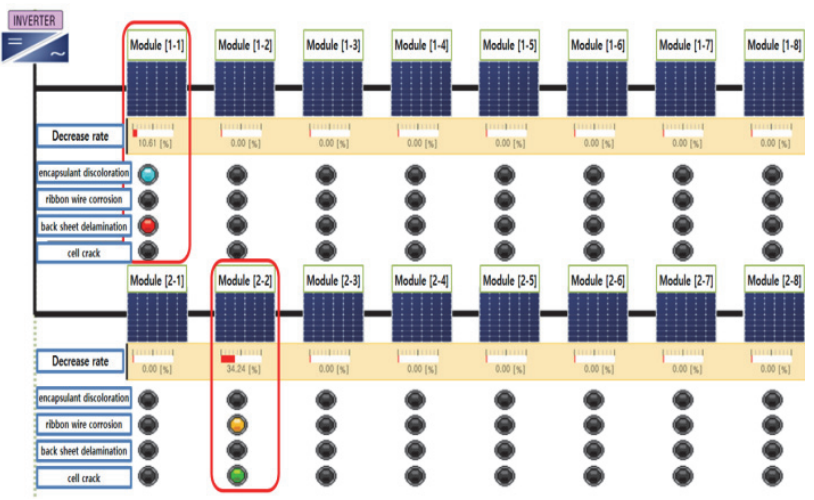

Figure 19 Evaluation menu of deterioration diagnosis system

\section{CONCLUSION}

This paper has performed a diagnosis algorithm of degradation condition for solar cell modules by taking into account the electrical performance and ambient factors according to the degradation diagnosis phenomenon of solar cell modules which are classified by the relevant ambient factor and electrical characteristics that are strongly related to the yearly degradation of solar cell modules. And also, this paper has implemented a diagnosis system of solar cell modules based on the evaluation algorithm. Furthermore, it is clear that the proposed diagnosis algorithm can properly perform a diagnosis of degradation conditions due to the fact that the electrical results of solar cell modules may be differently changed according to the degradation conditions.And it is confirmed that degradation condition of solar cell modules can be estimated correctly by taking into account the ambient conditions by the analysis approach which can change the electrical characteristics and degradation phenomenon depending on environmental factors.Besides as the results, the proposed degradation diagnosis can accurately decrease the output rate power based on the gauge bar function and presents an instruction of alert lamp according to the degradation condition. Finally, from the test results with the proposed algorithm and diagnosis system of solar cell modules, it is confirmed that they are practical and useful to enhance performance of the solar cell modules.

\section{Acknowledgements}

This work was supported by the Power Generation \& Electricity Delivery Core Technology Program of the Korea Institute of Energy Technology Evaluation and Planning (KETEP) granted financial resource from the Ministry of Trade, Industry \& Energy, Republic of Korea (No. 20182410105070 and 20206910100090 ).

\section{REFERENCES}

[1] Kibert, C. J. \& Fard, M. M. (2012). Differentiating among low-energy, low-carbon and net-zero-energy building strategies for policy formulation. Building Research \& Information, 40(5), 625-637.

https://doi.org/10.1080/09613218.2012.703489
[2] Si, H., Qi, Y., Zheng, M., Ren, Y., \& Yu, L. (2018). Structured peer-to-peer-based publication and sharing of ontologies to automatically process SPARQL query on a semantic sensor network. International Journal of Distributed Sensor Networks, 14(10). https://doi.org/10.1177/1550147718797581

[3] Tan, M., Yu, J., Huang, Q., \& Wu, W. (2018). Click data guided query modeling with click propagation and sparse coding. Multimedia Tools and Applications, 77(17), 2214522158. https://doi.org/10.1007/s11042-018-5703-4

[4] Yu, J., Zhang, B., Kuang, Z., Lin, D., \& Fan, J. (2017). Privacy: Image Privacy Protection by Identifying Sensitive Objects via Deep Multi-Task Learning. IEEE Transactions on Information Forensics and Security, 12(5), 1005-1016. https://doi.org/10.1109/TIFS.2016.2636090

[5] Seo, J., Hernandez, J., \& Gordillo, G. (2017). Solar Market and Policy Issues. Korea Photovoltaic Society, 3(2), 94-99.

[6] Yu, Z., Yu, J., Xiang, C., Fan, J., \& Tao, D. (2018). Beyond Bilinear: Generalized Multimodal Factorized High-Order Pooling for Visual Question Answering. IEEE Transactions on Neural Networks and Learning Systems, 29(12), 59475959. https://doi.org/10.1109/TNNLS.2018.2817340

[7] Yin, Y., Zhang, W., Xu, Y., Zhang, H., Mai, Z., \& Yu, L. (2019). QoS Prediction for Mobile Edge Service Recommendation with Auto-encoder. IEEE Access. https://doi.org/10.1109/ACCESS.2019.2914737

[8] Yuyu, Y., Lu, C., Yueshen, X., \& Jian, W. (2018). LocationAware Service Recommendation with Enhanced Probabilistic Matrix Factorization. IEEE Access, 6, 6281562825. https://doi.org/10.1109/ACCESS.2018.2877137

[9] Kang, G. H., Kim, K. S., Park, C.H., Yu, G.J., Ahn, H. K., \& Han, D. Y. (2009). Analysis of Durability and Drop rate of Maximum Output Power for Field aged Photovoltaic Modules. 24th Euro-solar cellSEC, 3349-3351. https://doi.org/10.4229/24thEUPVSEC2009-4AV.3.17

[10] Yuyu Yin, Yueshen Xu, Wenting Xu, Min Gao, Lifeng Yu, Yujie Pei (2017). Collaborative Service Selection via Ensemble Learning in Mixed Mobile Network Environments. Entropy, 19(7), 358. https://doi.org/10.3390/e19070358

\section{Contact information}

Donghyun TAE, PhD Student

Dept. of Electrical, Electronics and Communication Engineering, Korea University of Technology and Education,

1600, Chungjeol-ro, Byeongcheon-myeon, Dongnam-gu, Cheonan-si, Chungcheongnam-do, 31253, Republic of Korea

E-mail: tdh2002@koreatech.ac.kr

Hudong LEE, PhD Student

Dept. of Electrical, Electronics and Communication Engineering, Korea University of Technology and Education,

1600, Chungjeol-ro, Byeongcheon-myeon, Dongnam-gu, Cheonan-si, Chungcheongnam-do, 31253, Republic of Korea

E-mail:Ihd714@koreatech.ac.kr

Daeseok RHO, Professor

(Corresponding author)

Dept. of Electrical, Electronics and Communication Engineering,

Korea University of Technology and Education,

1600, Chungjeol-ro, Byeongcheon-myeon, Dongnam-gu, Cheonan-si, Chungcheongnam-do, 31253, Republic of Korea

E-mail: dsrho@koreatech.ac.kr 